\title{
John Maynard Keynesin talouspolitiikka ja suomalaiset keynesiläisen talouspolitiikan määritelmät
}

\author{
Jussi Ahokas,YTM, jatko-opiskelija, Itä-Suomen yliopisto'
}

\begin{abstract}
Abstrakti
Artikkelissa perehdytään John Maynard Keynesin pääteoksensa General Theoryn julkaisun jälkeen muotoilemaan talouspoliittiseen ohjelmaan ja verrataan sitä suomalaisiin määritelmiin keynesiläisestä talouspolitiikasta. Artikkeli osoittaa, että Keynesin politiikkaohjelman teoreettiset perustelut ja sisällöt eroavat merkittävästi niistä perusteluista ja sisällöistä, joihin Suomessa yleisimmin käytetty määritelmä keynesiläisestä talouspolitiikasta on nojannut. Kun keynesiläinen talouspolitiikka määritellään Keynesin oman talouspoliittiseen ohjelman perusteella, voidaan suomalaisen talouspolitiikan analyysiin tuoda uudenlaisia näkökulmia, jotka täydentävät ja tarkentavat kuvaa Suomen talouspolitiikan eri vaiheista ja sitä muovanneista vaikutteista.
\end{abstract}

Avainsanat: John Maynard Keynes; keynesiläisyys; talouspolitiikka

\section{Johdanto}

Globaalin finanssikriisin jälkeen keynesiläisestä talouspolitiikasta on keskustelu enemmän kuin vuosikymmeniin. Finanssikriisin työnnettyä läntiset taloudet syvään taantumaan vuosien 2008 ja 2009 aikana valtiot toisensa jälkeen julkistivat ja toimeenpanivat valtavia elvytyspaketteja, joista osaa perusteltiin vetoamalla eksplisiittisesti John Maynard Keynesin ajatteluun (ks. Ahokas ja Holappa 2014a). Hetken aikaa näytti siltä, että finanssipolitiikka oli nousemassa talouden ohjauksen keskiöön ja aseeksi suhdannevaihteluita vastaan.

Julkisessa keskustelussa vastasyklistä finanssipolitiikkaa eli julkisten tulojen ja menojen säätelyä on pidetty Keynesin talouspolitiikan peruskivenä. Suomen talouspolitiikan historiallista kehitystä käsittelevässä tutkimuskirjallisuudessa 
Keynesin talouspoliittisia suosituksia on tulkittu hienovaraisemmin. Tässäkin keskustelussa yleisin johtopäätös on kuitenkin ollut se, että keynesiläinen talouspolitiikka määrittyy ensisijaisesti finanssipolitiikaksi, jolla pyritään tasoittamaan talouden ja ennen kaikkea työllisyyden vaihteluita. Tämän näkemyksen tunnetuimmat edustajat lienevät taloustieteilijät Jukka Pekkarinen ja Juhana Vartiainen, jotka ovat teoksessa Suomen talouspolitiikan pitkä linja kattavasti perustelleet näkemyksensä (ks. Pekkarinen ja Vartiainen 1993; ks. myös Pekkarinen 1988).

Tässä artikkelissa tätä näkemystä ja muita suomalaisia määritelmiä keynesiläisestä talouspolitiikasta verrataan Keynesin politiikkasuosituksiin, jotka hän muotoili pääteoksensa General Theoryn (Keynes 1936) kirjoittamisen jälkeen. Keynesin talouspoliittinen ajattelu muuttui oleellisesti General Theoryn kirjoittamisen aikana ja hänen pääteoksessaan ja 1940-luvun alun kirjoituksissaan esittämät politiikkasuositukset erosivat merkittävästi hänen 1920-luvulla sekä 1930-luvun alussa suosittelemastaan politiikasta. Kun aiemmin Keynesin talouspolitiikan tavoitteena oli talouden tasapainottumisen vauhdittaminen, General Theoryn kirjoittamisen jälkeen Keynes määritteli talouspolitiikan päätavoitteeksi täystyöllisyyden ylläpitämisen ja kroonisen alityöllisyyden voittamisen. Tavoitteen saavuttamisen mahdollistaisi Keynesin mukaan ennakoiva ja ehkäisevä julkinen investointipolitiikka, jota Keynes suositteli toisen maailmansodan jälkeisen rauhanajan talouspolitiikaksi.

Artikkelissa esitetty tiivistelmä Keynesin "politiikkaohjelmasta" laajentaa aikaisempia koosteita Keynesin General Theoryn jälkeisistä talouspoliittisista suosituksista (vrt. Kregel 1985; 1994-1995; Brown-Collier ja Collier 1995). Sen pohjalta artikkelissa osoitetaan, että Keynesin 1930-luvun lopun ja 1940luvun alun talouspoliittiset suositukset määrittelevät keynesiläisen talouspolitiikan jokseenkin erilaiseksi kokonaisuudeksi kuin se on suomalaisessa julkisessa keskustelussa tai aikaisemmissa suomalaisissa tieteellisissä teksteissä määritelty. Tällä tulkintaerolla on erityisesti merkitystä silloin, kun pyritään arvioimaan ja jäsentämään suomalaisen talouspolitiikan kehitystä ja vaikutteita toisen maailmansodan jälkeen.

Tällä hetkellä kotimaisessa tutkimuksessa vallitseva käsitys on ollut pitkälti Pekkarisen ja Vartiaisen tulkinnan mukaisesti se, ettei suomalainen talouspolitiikka ole ollut keynesiläistä (esim. Kangas ja Saloniemi 2013, Okko 2008, Saari 2005, 19). Kun keynesiläinen talouspolitiikka ymmärretään Keynesin 
itsensä ajaman talouspolitiikan mielessä, ei Pekkarisen ja Vartiaisen johtopäätös ole enää itsestään selvä. Vaikka tässä artikkelissa ei analysoida suomalaisen talouspolitiikan historiallista kehitystä yksityiskohtaisesti, antavat sen havainnot tukea esimerkiksi Juha Tarkan (1993) Pekkarisen ja Vartiaisen tulkintaa kohtaan esittämälle kritiikille.

Keynesiläisen talouspolitiikan määritelmän tarkastelu on kiinnostavaa ennen kaikkea siksi, että sen kautta kuva Suomen talouspolitiikan eri vaiheista ja sitä muovanneista vaikutteista täydentyy ja tarkentuu. Sillä voi olla myös laajempaa yhteiskunnallista merkitystä, jos määritelmän muuttuminen samalla muuttaa tulkintaa ja itseymmärrystä suomalaisesta talouspolitiikasta. Mikäli yleisesti ajatellaan, että Suomen taloudellinen menestystarina toisen maailmansodan jälkeen tapahtui anti-keynesiläisen talouspolitiikan siivittämänä, suhtaudutaan keynesiläiseen talouspolitiikkaan politiikkaa suunnitellessa varauksellisemmin kuin siinä tapauksessa, että talouspolitiikka 1940-luvulta eteenpäin ymmärrettäisiin keynesiläisenä.

Artikkelin toisessa luvussa esitetään Keynesin pääteoksessa ja sen jälkeisissä teksteissä esittämän kansallisen talouspoliittisen ohjelman perusteet peilaten niitä Keynesin talousteoreettiseen ajatteluun ja sen kehitykseen. Kolmannessa luvussa tarkastellaan sitä, miten keynesiläinen talouspolitiikka on määritelty suomalaisessa talouspolitiikan tutkimuksessa ja verrataan tätä näkemystä toisessa luvussa esitettyyn kuvaan Keynesin talouspolitiikasta. Neljännessä luvussa esitetään artikkelin johtopäätökset.

\section{Keynesin General Theoryn jälkeisen talouspolitiikan perusteet}

John Maynard Keynesin henkilöä tarkasteltaessa on mahdotonta erottaa taloustieteilijää, virkamiestä ja talous- sekä yhteiskuntapoliitikkoa toisistaan. Elämänsä aikana Keynes ehti toimia muun muassa virkamiehenä Intian asioista vastanneessa virastossa, Ison-Britannian neuvottelijana Pariisin rauhankonferenssissa ja toisen maailmansodan jälkeistä kansainvälistä talousjärjestelmää rakentaneissa Bretton Woods -neuvotteluissa, ensimmäisen maailmansodan rauhanpolitiikan kriitikkona, 1920-luvun talouspolitiikan kriitikkona, sotatalouden suunnittelijana sekä sodanjälkeisen talouspolitiikan 
hahmottelijana. (Skidelsky 2003; Moggridge 2002.)

Edellinen listaus kuvaa hyvin sitä laajuutta, jolla Keynes osallistui talousja yhteiskuntapoliittiseen keskusteluun. Kuten Elizabeth Johnson (1974) on kuvannut, Keynes piti itseään taloustieteilijänä mutta samalla koko maailman taloudellisena neuvonantajana, opettajana ja suostuttelijana, jonka tehtävänä oli tuottaa tietoa yleisen mielipiteen muokkaamiseksi ja lopulta kokonaisuudessaan järkevän politiikan toteuttamiseksi. Keynes ei koskaan epäröinyt esittää omia ja joskus myös muiden ideoita lehtiartikkeleissaan, pamfleteissaan, neuvotteluissa, virkamiesmuistioissa tai akateemisessa kirjeenvaihdossa.

Keynesin talouspoliittisen ajattelun murros - hyökkäävästä puolustavaan strategiaan

Keynesin poliittista toimintaa ja hänen poliittisia mielipiteitään analysoitaessa on tärkeä ymmärtää, että hänen näkökantansa elivät jatkuvasti ja muuttuivat hänen taloustieteellisen ajattelunsa kehityksen mukana. Tämä koski erityisesti kansallista talous- ja työllisyyspolitiikkaa, johon tässä artikkelissa keskitytään. Esimerkiksi Keynesin talouspoliittiset suositukset kansainvälisen talouden järjestämiseksi jätetään tämän artikkelin tarkastelun ulkopuolelle.

Kregel (1994-1995, 262-265) on kuvannut, kuinka Keynesin kansallista talouspolitiikkaa koskevat suositukset muuttuivat 1930-luvulta 1940-luvulle tultaessa. Suuren laman jälkihoidossa Keynesin politiikkasuositukset muodostivat Kregelin sanoin hyökkäävän politiikkastrategian, jonka tarkoituksena oli saada aikaan nopeaa helpotusta pitkässä lamassa kärvistelleeseen talouteen. Tuolloin Keynesin politiikkasuosituksia olivat muun muassa hätäaputyöt, velaksi tapahtuneet julkiset menonlisäykset sekä julkiset investointihankkeet.

Hyökkäävä politiikkastrategia nojautui teoreettiseen ajatteluun, jonka Keynes esitti vuonna 1930 julkaistussa Treatise on Money -teoksessa (ks. Keynes 1930a). Teoksen kantava idea oli se, että politiikkatoimenpiteet katkaisisivat alenevien hintojen kierteen nopeammin kuin mihin markkinavoimat pystyisivät (Kregel 1994-1995, 263). Kuten esimerkiksi Minsky (1975, 8-11) on osoittanut, 1920-luvun ja 1930-luvun vaihteessa Keynesin ajattelu nojasi vielä voimakkaasti klassiseen talousajatteluun, jossa hintojen sopeutumisen jäykkyydet olivat keskeisessä asemassa. 1940-luvulla Keynesin talouspoliittinen strategia muuttui puolustavaksi sen jälkeen, kun hän oli tehnyt tietoisen 
teoreettisen irtioton klassisesta ajattelusta. Puolustavan strategian tarkoituksena oli pyrkiä säilyttämään täystyöllisyys myös rauhanaikana vastaamalla kapitalistisen rahatalouden krooniseen alikysynnän ongelmaan.

\section{KeYNeSin YLEINEN TEORIA}

Keynesin talouspoliittisen ajattelun murros liittyy pitkälti General Theoryssa esitetyn niin sanotun tuotannon rahateorian synnyttämiseen. Tuotannon rahateoria on käsite, jolla Keynes itse kuvasi sitä teoreettista kokonaisuutta, jota hän alkoi 1930-luvun alussa kehitellä luennoissaan ja kirjoituksissaan (ks. Davidson 1972; Chick 1983; Dillard 1980; Kregel 1998; Fontana ja Realfonzo 2005; Wray 2007). Suuren laman pitkä varjo oli alkanut vaikuttaa Keynesin ajatteluun. Hän halusi luoda teorian, joka selittäisi aikansa talousteorioita paremmin, miksi taloudet toistensa jälkeen ajautuivat 1920-luvun ja 1930luvun vaihteessa syvään kriisiin ja suurtyöttömyyteen (Minsky 1975, 7).

Keynesin (1963) mukaan vallitsevan klassisen talousteorian ongelma oli siinä, että se kuvasi talousjärjestelmää, jossa rahalla ei ollut käytännössä minkäänlaista roolia. Klassinen teoria käsitteli vaihtokauppajärjestelmää, jossa raha oli "jollain tavalla neutraalia" (Keynes 1963, 7). ${ }^{2}$ General Theoryn johdannossa Keynes (1936, vii) määrittelee rahatalouden taloudeksi, jossa "muuttuvat näkemykset tulevaisuudesta voivat vaikuttaa työllisyyden määrään, ei pelkästään sen suuntaan”. Tällä Keynes viittasi siihen, että klassisessa talousteoriassa oletettiin työllisyyden heilahtelevan tietyn normaalitason - ja samalla täystyöllisyystason - ympärillä (Chick 1983, 8).

Keynesin teoriassa klassisen teorian mukaista normaalitasoa ei lainkaan ole, vaan työllisyys voi jäädä pitkäksi ajaksi tai jopa pysyvästi potentiaalisen täystyöllisyyden alapuolelle. Keynesin $(1936,250)$ mukaan täystyöllisyys on rahataloudessa "harvinainen ja lyhyesti eletty sattumus". Yleisimmin rahataloudessa ollaan äärimmäisten suhdanteiden välimaastossa, mikä "ei ole toivoton eikä tyydyttävä" olotila (emt.).

Se, että rahatalous ei hakeudu automaattisesti täystyöllisyyteen, riippuu ennen kaikkea yrittäjien odotuksista, joilla on suuri rooli Keynesin teoriassa. Keynesin kuuluisa efektiivisen kysynnän periaate osoitti, kuinka yrittäjien odotukset kokonaiskysynnän ja kokonaistarjonnan kehityksestä luovat olosuhteet, joissa yrittäjille ryhmänä ei synny kannustimia työllistää lisää niin pitkään, että täystyöllisyys saavutettaisiin (emt., 23-34). Näin ollen Sayn laki, 
jonka mukaan tarjonta luo aina oman kysyntänsä, ei toteudu ja talous voi jäädä staattiseen "tasapainoon" selvästi potentiaalisen täystyöllisyyden alapuolelle.

Tärkein syy liian alhaisiin odotuksiin kysynnän kehityksestä liittyy Keynesin teoriassa investointien dynamiikkaan. Keynesin (1936, 147-164) mukaan investointeja määrittelevät niin kutsutut pitkän aikavälin odotukset, jotka ovat luonteeltaan hataria ja jatkuvasti muuttuvia. Koska investoijat eivät tunne tulevaisuutta ja pitkällä tähtäimellä investointipäätöksen kannalta tärkeät tekijät voivat kehittyä melkeinpä mihin suuntaan tahansa, ei investointipäätöksiä voida perustaa tieteelliseen kalkylointiin (Keynes 1937). Investoijat eivät yksinkertaisesti tiedä tulevaisuutta, mutta siitä huolimatta heidän on tehtävä tulevaisuutta koskevia päätöksiä. Siksi investointeja määrittelevät rahataloudessa sijoittajien tunnelmat eli Keynesin sanoin eläimelliset vaistot (Keynes 1936, 161).

Toisin kuin klassisessa teoriassa ja vielä moderneissakin makroteorioissa, Keynesin teoriassa investoinnit syntyvät autonomisesti sijoittajien muuttuvien ja epäselvien odotuksien ja oletuksien pohjalta. Klassisessa teoriassa säästäminen ajaa investointeja korkomekanismin kautta siten, että säästämisen lisääntyessä, kulutuksen vähentyessä ja kokonaiskysynnän supistuessa korko laskee ja kannustaa sijoittajat ja yrittäjät lisäämään investointejaan (ks. Keynes 1936, 177). Lopulta kasvaneet investoinnit kattavat aina lisääntyneen säästämisen, ja yrittäjät voivat luottaa kokonaiskysynnän riittävän aina kattamaan kokonaistarjonnan. Siksi heidän kannattaa työllistää periaatteessa niin pitkään, kunnes lisää työvoimaa ei enää ole käytettävissä.

Keynesin mukaan korko ei kuitenkaan tasapainota rahataloudessa säästämistä ja investointeja, vaan likviditeetin kysynnän ja tarjonnan eli toisin sanoen yhteisön halun pitää varallisuutta likvidissä muodossa sekä pankkijärjestelmän kyvyn ja halun luoda likviditeettiä talouteen. Luomalla klassiselle korkoteorialle vaihtoehtoisen likviditeettipreferenssikorkoteorian (emt., 194-209) Keynes kiisti korkomekanismin toiminnan talouden tasapainottajana.

Keynesillä investointien lisäksi myös säästäminen on rahataloudessa autonominen toimenpide, minkä vuoksi yhteisön säästämishalukkuus ja investointihalukkuus eivät automaattisesti kohtaa. Vaikka säästämisen ja investointien yhtäsuuruus voidaan aina havaita, on tämä seurausta siitä, että investointien määräämä kokonaistulotaso määrittää lopulta sen, kuinka paljon kulloinkin voidaan säästää (emt., 52-65). 
Toteutunut säästäminen ei välttämättä vastaa yhteisön säästämistavoitetta, mikä voi kannustaa yhteisöä säästämään enemmän. Koska investoinnit elävät omaa elämäänsä ja yleensä jopa supistuvat säästämisen lisääntyessä, voivat säästämistavoitteet jäädä pitkään toteutumatta. Tällöin talouteen syntyy negatiivinen kierre, taantuma ja pahimmassa tapauksessa lama, jolloin myös työttömyys lisääntyy nopeasti. Vastaavasti silloin, kun yhteisön säästämistavoitteet toteutuvat ja investoinnit kehittyvät suotuisasti, muodostuu rahatalouteen positiivinen kierre ja työttömyys vähenee. Keynesin "yleinen teoria" selittää tällä tavoin myös talouden suhdannevaihtelut ja kriisit.

Keynesin teorian mukaan rahatalouden yleinen dynamiikka on, että toteutuneet kokonaiskysynnän muutokset vaikuttavat yrittäjien ja sijoittajien odotuksiin sekä määrittävät investointien ja efektiivisen kysynnän tason, joka puolestaan määrittää työllisyyden tason. Syntyneet olosuhteet vaikuttavat edelleen yrittäjien odotuksiin ja taloudellinen kehitys jatkuu dynaamisesti. Vaikka tietyt instituutiot luovat rahatalouteen vakautta, on se kuitenkin rakenteellisesti epävakaa talousjärjestelmä (Keynes 1936, 250). Tärkein muuttuja talouden kehityksen taustalla on investointitoiminta, koska siihen liittyy suurin epävarmuus, jossa investoijien tunteet ja tunnelmat näyttelevät suurta roolia (Keynes 1937).

\section{Talouspolitilkka General Theoryssa}

Keynes piti itsestään selvänä, että edellä kuvattujen dynamiikkojen vuoksi yksityiset investoinnit eivät pysty takaamaan täystyöllisyyttä rahataloudessa. Tämä näkemys vaikutti oleellisesti Keynesin talouspoliittiseen ajatteluun. Pääteoksensa lopussa Keynes $(1936,372)$ mainitseekin kapitalistisen rahatalousjärjestelmän keskeisemmäksi ongelmaksi sen "epäonnistumisen täystyöllisyyden tuottamisessa ja sen tuottaman sattumanvaraisen ja epäoikeudenmukaisen varallisuuden ja tulojen jakautumisen”. Työllisyysongelma ei siis ole Keynesille enää suhdanneluontoinen, kuten vielä 1930-luvun alussa, vaan se on krooninen.

Rahatalouden kyvyttömyys tuottaa täystyöllisyyttä johtuu taloudellisten toimijoiden säästämishalukkuuden ja investointihalukkuuden epätasapainosta. Keynes (emt., 373) tuomitseekin klassisesta teoriasta johdetun politiikkasuosituksen, jonka mukaan säästämiseen kannustamalla talouden pääomakanta 
saadaan kehittymään suotuisasti ja talouden varallisuus saadaan kasvamaan. Rahataloudessa asia on Keynesin mukaan juuri päinvastoin.

Yleensä säästämiseen on kannustettu pitämällä talouden korkotaso korkealla, mikä Keynesin teorian mukaan rajoittaa investointeja (emt., 375). Keynes (emt., 376) suositteleekin matalan koron politiikkaa, joka samalla tasoittaisi myös tulonjakoa kokonaiskysyntää suosivasti. Myös esimerkiksi verotukseen liittyvillä toimilla yhteisön kulutusalttiutta voidaan lisätä ja siten efektiivistä kysyntää voidaan kasvattaa (emt., 378).

Keynes ei kuitenkaan usko, että pelkästään korkopolitiikalla voitaisiin saavuttaa optimaalinen ja täystyöllisyyden takaava investointiaste. Hänen mukaansa vasta "jokseenkin kattava investointien yhteiskunnallistaminen" luo edellytykset täystyöllisyyden turvaamiselle (emt., 378). Julkisen vallan tehtäväksi tuleekin pitää huoli siitä, että yhteiskunnassa investointihalukkuus pysyy kaikkina aikoina niin korkealla, että täystyöllisyys saavutetaan.

General Theoryssa esitettyjen talouspoliittisten näkökulmien pohjalta Keynes osallistui 1940-luvun alussa keskusteluun Ison-Britannian rauhanajan talouspolitiikasta. Kregelin (1994-1995, 265) mukaan Keynesin esittämä talouspolitiikan strategia oli nyt muuttunut puolustavaksi strategiaksi, jonka tavoitteena oli jatkuvalla talouspoliittisella ohjauksella säilyttää sodanaikana saavutettu täystyöllisyys myös tulevina vuosina ja vuosikymmeninä. Täystyöllisyydessä Keynes ajatteli talouden työttömyysasteen olevan kolmesta viiteen prosenttia (Kregel 1994-1995, 266).

Keynesin talouspoliittinen ohjelma General Theoryn jälkeen

Keynes esitti ajatuksensa kansalliseksi talouspolitiikaksi Ison-Britannian valtiovarainministeriön sodanjälkeisen jälleenrakennuksen ja rauhanajan talouden suunnittelun yhteydessä Keynesin ystävän ja kollegan James Meaden houkuteltua hänet mukaan keskusteluun (ks. Keynes 1980, 314). Keynesin ajatus talouspoliittisesta puolustusstrategiasta käy ilmi hyvin hänen Meadelle lähettämästään kommentista, jossa Keynes $(1980,326)$ kritisoi Meadea siitä, että tämä laittaa omassa esityksessään rauhanajan talouspolitiikaksi liikaa painoa laskusuhdanteen "korjaamiseen ja liian vähän ennaltaehkäisyyn".

Keynesin $(1980,326)$ mukaan monet lyhyen aikavälin suhdannetta tasapainottavat toimet, kuten esimerkiksi taantuman jo alettua käynnistettävä 
julkinen työllistämistoiminta, ovat kömpelöitä tapoja vaikuttaa taloudelliseen kehitykseen. Lisäksi niiden tehokkuus voi osoittautua heikoksi. Korjaavien toimenpiteiden sijasta Keynes suosittelee vakaata pitkän tähtäimen ohjelmaa, jonka keskiössä on julkisesti ohjattu investointitoiminta, mutta johon kuuluu myös esimerkiksi pysyväisluonteinen julkinen työllistämistoiminta. Tällaisella ohjelmalla on mahdollista pienentää huomattavasti vakavien heilahtelujen todennäköisyyttä, jolloin erityisiä korjaavia toimenpiteitä ei lainkaan tarvita.

Kuten General Theoryssa, myös 1940-luvun alun teksteissä Keynesin tärkeimpänä pitkän tähtäimen politiikkatavoitteena on täystyöllisyyden ylläpitäminen. Keynes $(1980,321)$ toistaa talouspolitiikan perusteluissaan General Theoryn johtopäätöksen, jonka mukaan täystyöllisyyden ylläpitäminen edellyttää sitä, että investointien määrä on niin suuri, että yhteisön säästämistavoitteet toteutuvat työllisyyden ja kokonaistulon tavoitellulla tasolla. Haluttu säästäminen riippuu yhteisön kulloisistakin "tavoista ja mahdollisuuksista", joihin vaikuttavat muun muassa verotus, erilaiset politiikat sekä yhteiskunnalliset näkemykset (Keynes 1980, 321). Olivat nämä mitä hyvänsä, täystyöllisyyspolitiikan tehtävänä on pitää huoli siitä, että olemassa olevissa olosuhteissa investointiaste on riittävän suuri kattamaan niin sanotun indikoidun säästämisen, eli yhteisön kulloisenkin säästämishalukkuuden (Keynes 1980, 321).

\section{SÄÄSTÄMISEN KANNUSTAMINEN JA INVESTOINTIEN KOHDENTAMINEN YLIKYSYNNÄN} TAITTAJANA

Keynesin $(1980,321)$ mukaan sodanjälkeiset taloudelliset olosuhteet ja siten myös täystyöllisyyspolitiikka voidaan jakaa kolmeen vaiheeseen sen mukaan, mikä on todennäköisesti halutun säästämisen ja investointien välinen suhde. Ensimmäisessä vaiheessa investointien määrä ylittää halutun säästämisen. Toisessa vaiheessa haluttu säästäminen ylittää investointien tason. Kolmannessa vaiheessa halutun säästämisen ja investointien välinen kuilu kasvaa yhä suuremmaksi.

Ensimmäinen vaihe on seurausta talouden tarjontapotentiaalin laskusta sodan seurauksena ja jälleenrakennuksen vaatimien resurssien suuruudesta. Sodan aikana säännöstelytaloutta ja Ison-Britannian ulkomaista rahoitusta suunnitelleelle Keynesille tämän vaiheen politiikkatoimet olivat tuttuja ja pitkälle pohdittuja. Keynes (1980, 267-270) kirjoitti vuonna 1942 sodan jälkeiseen rakentamisohjelmaan liittyen: 
Toinen tehtävämme on estää liikakysynnän syntyminen suhteessa fyysisiin tarjontamahdollisuuksiin, mikä tarkoittaisi inflaatiota. Näin siksi, että fyysiset tarjontamahdollisuutemme ovat kaukana rajattomista. Rakennusohjelmamme pitää olla hyvin mitoitettu suhteessa niihin resursseihin, joita on jäljellä, kun olemme täyttäneet päivittäiset tarpeemme ja tuottaneet tarpeeksi vientihyödykkeitä maksaaksemme niillä sen mitä meidän tarvitsee tuoda ulkomailta. [...] Kun olemme täyttäneet päivittäiset tuotantotarpeemme ja viennin tarpeet, meillä on varmasti jonkinlainen ylijäämä resursseja ja työvoimaa käytettäväksi parannusinvestointeihin (suom. JA).

Talouspolitiikalla oli siis huolehdittava riittävästä kulutushyödykkeiden ja vientituotteiden tuotannosta, jotta reaalinen elintaso kehittyisi suotuisasti eikä talouden ulkoinen tasapaino romahtaisi. Vasta tämän jälkeen tuli investointien tekemisen vuoro. Keynesin mukaan ensimmäisessä vaiheessa sodan jälkeen inflaatiopaine on niin suuri, että täystyöllisyystasapainon saavuttaminen edellyttää sekä investointien rajoittamista että kulutuksen säännöstelyä asianmukaisin toimenpitein. Kulutustarpeiden tyydyttäminen olisi aluksi ensisijaista, jolloin investointirajoitteet ja investointiluvat olisivat tärkein politiikkatoimenpide (Keynes 1980, 322).

Pavlina Tscherneva $(2008 ; 2012)$ on kuvannut yksityiskohtaisesti Keynesin hahmottelemaa täystyöllisyyspolitiikkaa korkeiden inflaatiopaineiden olosuhteissa toisen maailmansodan aikana. Politiikan ytimessä olivat kohdennetut työllistämistoimet, investointien rajoittaminen ja porrastaminen sekä kulutuksen vähentäminen ja uudelleenkohdentaminen (Tscherneva 2008, 14-16). Keynes ei ollut valmis luopumaan työllisyystavoitteista estääkseen inflaation kiihtymisen, vaan uskoi säästämisen lisäämisen riittävissä määrin olevan mahdollista ylikysynnän hallitsemiseksi. Välittömästi sodan jälkeen nämä politiikkatoimet olivat edelleen ajankohtaisia.

\section{PERUSONGELMA: INVESTOINNIT KATTAMAAN YHTEISÖN SÄÄSTÄMISHALUKKUUS}

Keynesin hahmottelema toinen taloudellisen kehityksen ja talouspolitiikan vaihe alkaisi, kun talouden tuotantorajoitteet vähitellen vähenisivät, jolloin sekä kulutukseen että investointeihin liittyvää sääntelyä voitaisiin purkaa. Tällöin taloudessa säästämishalukkuus ylittäisi investointihalukkuuden, jolloin 
talouspolitiikka pitäisi suunnata investointien riittävän tason ylläpitämiseen. Keynesin politiikka näihin olosuhteisiin on pitkän tähtäimen investointiohjelma, jossa investoinnit, joihin julkiset tai puolijulkiset tahot voivat vaikuttaa, muodostaisivat kaksi kolmasosaa tai jopa kolme neljäsosaa kokonaisinvestoinneista (Keynes 1980, 322).

Keynes ei nähnyt, että valtion pitäisi ottaa investointitoiminta suoraan poliittiseen ohjaukseen (Kregel 1985). Parhaiten investointien yhteiskunnallistamistehtävään sopisivat Keynesin (1972, 288-289) mukaan sellaiset tahot, joiden toiminta tähtää lähtökohtaisesti yhteiskunnalliseen hyvään, ja on luonteeltaan julkista, mutta kuitenkin autonomista siinä mielessä, että esimerkiksi parlamentti voisi puuttua siihen vain viimekätisesti erityistapauksissa. Tällaisia tahoja ovat Keynesin mukaan esimerkiksi yliopistot, Englannin Pankki, Lontoon satamaviranomainen ja valtio-omisteiset osakeyhtiöt (Brown-Collier \& Collier 1995, 342; Kregel 1994-1995, 266). Yleisemminkin varauksellisesti poliitikkoihin suhtautunut Keynes näki parlamentin suuressa investointivallassa niin sanotun siltarumpupolitikoinnin vaaran.

Kun talouden investointiaste pysyisi julkisesti ohjatun investointitoiminnan seurauksena jatkuvasti korkealla, myös suhdanneheilahtelut jäisivät pieniksi. Tällöin korjaavaa suhdannepolitiikkaa, esimerkiksi vastasyklistä julkisten tulojen ja menojen säätelyä, ei tarvittaisi. Tämä on Keynesin sodanjälkeisen talouspolitiikan ydin. Keynes $(1980,323)$ arvioi, että toimivan pitkän aikavälin investointiohjelman laajuus liikkuisi todennäköisesti 7,5 ja 20 prosentin välillä suhteessa kansantuloon. Ohjelma mahdollistaisi myös sen, että julkisia investointeja voitaisiin toteuttaa vastasyklisesti, jos kaikesta huolimatta taloudessa tapahtuisi suuria heilahduksia (emt.).

Toisin kuin yleensä esitetään, Keynesin suosittelemassa talouspolitiikassa ainoa merkittävä vastasyklinen elementti ovat julkisesti ohjatut investoinnit. Keynes (1980, 319, 323-324, 406) suhtautui hyvin varauksellisesti lyhyen aikavälin julkisten tulojen ja menojen säätelyyn, vaikka hyväksyikin James Meaden ehdotuksen sosiaalivakuutusmaksujen vaihtelusta työllisyystilanteen mukaan (Keynes 1980, 277). Keynes $(1980,353)$ perusteli nihkeää suhtautumistaan päätösperäiseen meno- ja tuloelvytykseen sillä, että verotulojen lasku tekisi budjetista joka tapauksessa elvyttävän laskusuhdanteessa. Lisäksi Keynes (1980, 366) näki, että liiallinen budjetin epävakaus voisi heikentää luottamusta ja vaikuttaa siten negatiivisesti yksityiseen investointitoimintaan. Kuten edellä 
todettiin, Keynes $(1980,323)$ ei myöskään pitänyt muita kertaluontoisia lyhyen aikavälin toimenpiteitä tehokkaina tai helposti toteutettavina.

Keynesin SUOSiTtelema BUdJETTIPOLITIIKKA

Kuten Brown-Collier ja Collier (1995, 345-350) ovat kuvanneet, Keynesin esitykset budjettipolitiikasta ovat yhteensopivia investointien yhteiskunnallistamispolitiikan ja pitkän tähtäimen ennaltaehkäisevän vakauttamispolitiikan kanssa. Yksi tärkeimmistä Keynesin esityksistä oli erityisen investointi- tai pääomabudjetin käyttöönotto julkisen sektorin budjetoinnissa. Keynesin $(1980,352,368)$ esittämässä investointibudjetissa tavoitteena oli arvioida kaikkien kansantalouden säästämisen ja investointien erien mennyttä ja tulevaa kehitystä ja sovittaa julkiset investointisuunnitelmat niiden kanssa siten, että täystyöllisyys saavutettaisiin.

Keynes suositteli, että tavallinen valtion menoja ja tuloja kuvaava budjetti pidettäisiin tasapainossa tai ylijäämäisenä, mutta syvissä kriiseissä alijäämät voitaisiin sallia eikä kulutusbudjettia pitäisi tällöin päätösperäisesti tasapainottaa. Investointibudjetti sen sijaan voisi olla yleisemmin alijäämäinen ja suuria investointihankkeita voitaisiin rahoittaa velalla (Brown-Collier ja Collier 1995, 346-347). Tavallisen budjetin ylijäämillä katettaisiin pidemmällä aikavälillä investointibudjetin alijäämiä (Keynes 1980, 407-408). Yhteiskunnallisia investointeja suunniteltaessa ja toteutettaessa tulisi Keynesin (emt., 407) mukaan arvioida sekä niiden suoraa rahamääräistä tuottoa että niiden pitkän aikavälin reaalista tuottoa. Yhteiskunnallisilla investoinneilla onkin Keynesin ajattelussa lyhyemmällä tähtäimellä keskeinen rooli täystyöllisyyden ylläpitämisessä ja pidemmällä tähtäimellä yhteiskunnan tuotantopotentiaalin ja muun yhteiskunnallisen hyödyn tuottamisessa.

Keynes $(1980,278)$ ei pitänyt investoinneista seurannutta julkista velkaantumista sinällään ongelmana ja uskoi valtion velan tai valtion takaaman velan määrän kasvavan sodanjälkeisinä vuosina. Keynes $(1980,320)$ oli tutustunut ja viehättynyt Abba Lernerin (1943) ajatuksesta, jonka mukaan julkisen velanoton tarve vähenisi ennen pitkää automaattisesti, kun yksityiselle sektorille velan vastinparina kumuloitunut varallisuus kannustaisi lisäämään kulutusta ja kasvattaisi valtion verotuloja siten, että valtionvelan korot voitaisiin maksaa niistä. Keynes (1980, 279-280) näki, että julkisella sektorilla valtion 
tulisi kantaa päävastuu investointien rahoituksesta, vaikka investointien kohdentaminen olisi tehokkainta paikallishallinnon tasolla.

Vaikka julkinen velka ei sinällään ole ongelma, Keynes $(1980,366)$ piti tärkeänä, että julkisen velan vastineeksi saadaan kansantulon kasvua tukevia investointeja, jolloin velka ja kansantulo kasvavat suurin piirtein samassa suhteessa. Keynes toisin sanoen ajatteli, että kohdistamalla velaksi tehdyt investoinnit oikein, ne rahoittaisivat itse itsensä siinä mielessä, että valtion velkasuhde pysyisi vakiona tai jopa pienenisi. Keynes $(1980,278)$ esittikin, että "epätuottavaa" velkaa vähennettäisiin valtion investointibudjetissa ja sitä korvattaisiin jatkuvasti "tuottavalla" velalla, jos lisäinvestointeja tarvittaisiin kattamaan yhteisön säästämishalukkuus. Silloin, kun investoinneille ei olisi tarvetta, voitaisiin myös menobudjetin ylijäämää käyttää investointivelan vähentämiseen.

\section{KULTAINEN AIKAKAUSI JA LIIKASÄÄSTÄMISEN HILLINTÄ}

Keynes oli taloudellisen kehityksen suhteen pessimistinen, eikä uskonut, että investoinnit pystyisivät kattamaan yhteisön säästämishalukkuuden pidemmällä aikavälillä. Päinvastoin talouskehityksen ja talouspolitiikan kolmannessa vaiheessa, jonka tarkkaa ajankohtaa Keynes ei uskaltanut ennustaa, säästämishalukkuuden ylijäämä kasvaisi investointeihin nähden entisestään. Tämä olisi seurausta mielekkäiden yksityisten investointitarpeiden vähenemisestä siinä määrin, että säästämishalukkuuden ja investointihalukkuuden epäsuhta voitaisiin kattaa ainoastaan tarpeettomilla ja resursseja hukkaavilla investoinneilla (Keynes 1980, 321).

Kolmannessa vaiheessa talouden vakauttaminen edellyttäisi Keynesin (1980, 323) mukaan kannustamista järkevän kulutuksen lisäämiseen ja säästämisen vähentämiseen lisäinvestointien sijaan. Tällä tavalla yhteisön kulutusalttius kasvaisi ja investointeja tarvittaisiin vähemmän efektiivisen kysynnän pitämiseen täystyöllisyystasolla. Keynes (emt.) esitti liiallisen säästämisen vähentämiseksi myös työajan lyhentämistä ja lomien pidentämistä. Tätä kautta tahaton rahamääräinen säästäminen vähenisi ja kulutukseen suuntautuisi suurempi osa kansantulosta, jolloin investointitarve vähenisi edelleen. Kun talouden kysyntärakenne muuttuisi tämän suuntaisesti, lopulta pelkästään pääoman kulumisen kattavat bruttoinvestoinnit voisivat riittää pitämään yllä täystyöllisyyttä (emt.). 
Kuten ensimmäisessä vaiheessa, myös kolmannessa vaiheessa Keynesin politiikkasuosituksena on kulutuksen suosiminen investointien ja tämän lisäksi vapaa-ajan suosiminen kulutuksen sijaan. Keynes (1980, 323) kutsuu kolmatta vaihetta talouden kultaiseksi aikakaudeksi. Keynes palaa talouspolitiikan hahmottelussaan jo vuonna 1930 kirjoittamansa esseen Economic Possibilities for our Grandchildren teemoihin ja niin kutsutun taloudellisen ongelman ratkaisemiseen.

Keynes (1930b) kuvasi esseessä taloudellisen ongelman ratkaisua seuraavasti:

Siispä ensimmäistä kertaa luomisensa jälkeen ihminen tulee kohtaamaan hänelle pysyvästi asetetun ongelman: kuinka käyttää vapauttaan painavista taloudellisista huolista, kuinka käyttää vapaa-aikaansa, jonka tiede ja koronkorko [talouskasvu] ovat hänelle voittaneet, elääkseen viisaasti, miellyttävästi ja hyvin (suom. JA).

Tällaisessa maailmassa ihmiset saattaisivat keskittyä perustarpeiden tyydytyksen ylittäviin toimiin, viettämään enemmän vapaa-aikaa ja kehittämään itseään henkisesti.

\section{Yhteenveto Keynesin talouspoliittisista suosituksista}

Keynesin General Theoryn jälkeen esittämä rauhanajan talouspolitiikka erosi merkittävästi hänen vielä 1930-luvun alussa suosittelemastaan talouspolitiikasta. Keskeinen syy tälle oli Keynesin talousteoreettisen ajattelun murros, joka vaikutti oleellisesti myös hänen talouspoliittisiin näkemyksiinsä. Keynesin 1940-luvulla hahmotteleman talouspolitiikan keskiössä oli talouden investointiasteen sovittaminen kulloisenkin säästämishalukkuuden mukaiseksi, jolloin täystyöllisyyden edellytykset hänen teoriansa mukaisesti toteutuisivat.

Keynesin rauhanajan kansallinen talouspolitiikka voidaan tiivistää seuraaviin kohtiin (vrt. Kregel 1985; 1994-1995; Brown-Collier ja Collier 1995):

1. Talouspolitiikan tärkeimmät tavoitteet ovat täystyöllisyys eli 3-5 prosentin työttömyysaste sekä tulojen ja varallisuuden tasaisempi 
jakautuminen.

2. Täystyöllisyyden saavuttaminen edellyttää investointien yhteiskunnallistamista, sillä rahapolitiikka sekä julkisen sektorin vastasyklinen tulojen ja menojen säätely eivät ole tarpeeksi tehokkaita toimia rahatalouden ohjauksessa.

3. Investointi- ja säästämishalukkuuden suhde vaihtelee taloudessa eri aikoina, jolloin tarvitaan erilaista talouspolitiikkaa. Pidemmällä aikavälillä säästämishalukkuus suhteessa investointihalukkuuteen kasvaa. Sodan jälkeen voidaan erotella tämän kehityksen osalta kolme eri vaihetta.

4. Investointipolitiikan tehtävänä on ennaltaehkäistä suhdannevaihteluita, jolloin lyhyen aikavälin vakautustoimia tarvitaan vähemmän. Lyhyen aikavälin vakauttaminen tulee tehdä investointiohjelmien sisällä säätelemällä julkisesti ohjattuja investointeja vastasyklisesti.

5. Investointipolitiikkaa tulee toteuttaa autonomisten julkisten ja puolijulkisten tahojen kautta siten, että julkisesti ohjattujen investointien kokonaismäärä on 7,5-20 prosenttia kansantulosta ja jopa kolme neljäsosaa kokonaisinvestoinneista. Investointiohjelmaa mitoitettaessa on jatkuvasti arvioitava yksityisen sektorin investointien kehitystä suhteessa yhteisön säästämishalukkuuteen.

6. Investointiohjelman hallitsemiseksi on siirryttävä investointibudjetointiin, jossa julkiset investointimenot erotetaan julkisista kulutusmenoista. Kulutusbudjetin tulee olla kaikkina aikoina ylijäämäinen tai vähintään tasapainossa. Investointibudjetti voi olla alijäämäinen ja investointeja voidaan rahoittaa velalla. Investointien suunnittelussa on huomioitava investoinnin suorat ja epäsuorat tuotot (so. kulutusbudjetin ylijäämä) sekä yhteiskunnalliset reaaliset tuotot.

7. Rahapolitiikassa tulee tavoitella matalaa korkotasoa, mikä vaikuttaa kokonaiskysyntään positiivisesti investointihalukkuuden ja tulonjaon välityksellä.

8. Julkisen sektorin velkaantuminen ei ole merkittävä ongelma etenkään 
matalien korkojen olosuhteissa. Valtion on kannettava paikallishallintoa suurempi vastuu julkisten hankkeiden rahoittamisesta.

9. Talouden lähestyessä täystyöllisyyttä investointien ja kokonaiskysynnän säätelyä tulee kohdentaa tarkemmin niille talouden alueille, joilla tuotantoresursseja on käyttämättä. Julkiset työllistämistoimet ja säästämiseen kannustaminen ovat lähellä täystyöllisyyttä keskeisiä politiikkatoimia.

10. Pitkällä aikavälillä investointitarpeiden vähentyessä täystyöllisyyden saavuttaminen edellyttää säästämiseen kannustamista, järkevän kulutuksen lisäämistä sekä vapaa-ajan lisäämistä työaikaa lyhentämällä ja lomia lisäämällä.

\section{Suomalaiset tulkinnat Keynesin talouspolitiikasta}

Tässä luvussa tarkastellaan, miten suomalaisessa tieteellisessä keskustelussa Keynesin talouspolitiikka on ymmärretty ja miten keynesiläinen talouspolitiikka on määritelty. Suomessa keskustelu Keynesin talouspoliittisesta perinnöstä on ollut jossain määrin vilkasta. Laajimmin keskustelua Keynesin talouspolitiikasta ja keynesiläisen talouspolitiikan määritelmästä on käyty Suomen talouspolitiikan historiaa käsitelleessä tutkimuksessa (ks. Pekkarinen 1988; Pekkarinen ja Vartiainen 1993, Tarkka 1988; 1993; Kiander 2001; Jäntti ja Vartiainen 2009).

Myös muutamissa yleisimmissä talousteoreettisen ja talouspoliittisen ajattelun kehitystä käsittelevissä katsausartikkeleissa ja tietokirjoissa on esitetty keynesiläisen talouspolitiikan määritelmiä (ks. Koskela 1996; Korkman 2015). Esimerkiksi Koskelan (1996) artikkelissa ei kuitenkaan käsitellä käytännössä lainkaan Keynesin teoriaa tai hänen talouspoliittisia suosituksiaan, vaan keynesiläinen talouspolitiikka määritellään eksplisiittisesti Keynesiä seuranneiden taloustieteilijöiden ja talouspolitiikan teoreetikkojen tieteellisen työn perusteella.

Taloustieteellisen ja taloushistoriallisen tieteellisen kirjallisuuden lisäksi keynesiläisen politiikan määritelmiä on esitetty yhteiskuntatieteellisessä kirjallisuudessa, jossa lähtökohtana on ollut valtiomuutos ja erilaiset taloudellisen 
kasvun sekä poliittisen ohjauksen regiimit (ks. esim. Heiskala 2006; Kananen 2014; Moisio 2012). Tässäkään kirjallisuudessa ei yleensä ole syvennytty Keynesin talousteoreettiseen ja talouspoliittiseen ajatteluun, vaan määritelmät ovat olleet luonteeltaan yleisempiä.

Seuraava tarkastelu keskittyy ensisijaisesti Suomen talouspolitiikan historiaa käsitelleessä tutkimuksessa esitettyihin määritelmiin Keynesin talouspolitiikasta, sillä näissä analyyseissa lähtökohtana on ollut useimmin eksplisiittisesti Keynesin talousteoreettinen ja talouspoliittinen ajattelu. Lisäksi näissä tutkimuksissa liikutaan konkreettisen talouspolitiikan tasolla, jolloin vertailu edellisessä luvussa esitettyyn Keynesin talouspoliittiseen ohjelmaan on mielekästä.

Keynesin General Theoryn kirjoittamisen jälkeen muotoilema talouspolitiikka osoitettiin edellisen luvun tarkastelussa täystyöllisyyden turvaamaan pyrkiväksi investointipolitiikaksi. Keynesin "yleisestä teoriasta” johdettuna tavoitteena hänen talouspolitiikassaan oli investointien sovittaminen kulloinkin vallitsevaan säästämishalukkuuteen siten, että täystyöllisyyden takaava efektiivisen kysynnän taso saavutetaan. Keynesin mukaan täystyöllisyyden ylläpitäminen edellyttää jonkinasteista investointien yhteiskunnallistamista, jota hän suositteli toteutettavaksi julkisten ja puolijulkisten tahojen investointitoiminnan kautta. Lisäksi Keynes suositteli matalien korkojen rahapolitiikkaa sekä budjettipolitiikkaa, joka mahdollistaisi tehokkaan julkisen investointitoiminnan ohjauksen.

Suomalaisessa tieteellisessä keskustelussa keynesiläinen talouspolitiikka on määritelty huomattavasti kapeammin. Esimerkiksi vaikutusvaltaisessa Suomen talouspolitiikkaa käsittelevässä teoksessaan Pekkarinen ja Vartiainen (1993, 53) määrittelevät keynesiläisen talouspolitiikan sisällön siten, että siinä ”on olennaista ajatus hintamekanismin puutteellisesta toimivuudesta ja pyrkimys täystyöllisyyden säilyttämiseen kokonaiskysyntää stabiloimalla, tarvittaessa alijäämäisin budjetein”. Määritelmän mukaisesti keynesiläinen politiikka on siis vastasyklistä julkisten menojen ja tulojen säätelyä, jonka tavoitteena on tasoittaa suhdannevaihteluita ja erityisesti työllisyydessä tapahtuvia heilahteluja.

Pekkarisen ja Vartiaisen määrittely ei ole ainoa laatuaan. Niin taloustieteen oppikirjoissa (esim. Pekkarinen ja Sutela 2002; Burda ja Wyplosz 2013), taloustieteellisissä tutkimuksissa (esim. Gali 2005; Krugman 2005) kuin populaarimmissa teksteissä (esim. Krugman 2015; Jahan ym. 2014; Kanniainen 2012) 
keynesiläinen talouspolitiikka ymmärretään nimenomaan vastasykliseksi finanssipolitiikaksi, jonka tehtävänä on vakauttaa talouden suhdannekiertoa tai elvyttää lamaan ajautuvaa kansantaloutta. Tämä näkemys vallitsee myös julkisessa keskustelussa. Esimerkiksi talousjournalismissa keynesiläinen politiikka määritellään usein vastasykliseksi finanssipolitiikaksi (esim. Giles 2013; Hurri 2010; 2014 ).

Pekkarinen ja Vartiainen (1993) esittävät, että vastasyklisen finanssipolitiikan lisäksi myös aktiivinen valuuttakurssipolitiikka, jolla on tarkoitus vaikuttaa työllisyyden kehitykseen, voidaan laskea keynesiläiseksi politiikaksi. Tätä he perustelevat sillä, että valuuttakurssipolitiikan taustalla täytyy ainakin implisiittisesti olla oletus hintajäykkyydestä ja erityisesti jäykistä nimellispalkoista, jotka tekevät mahdolliseksi kokonaistarjonnan lisäämisen inflaatiota kiihdyttämällä (emt., 53). Tässä perustelussa hintajäykkyydet nähdään Keynesin teorian kulmakivenä.

Jotakuinkin saman näkemyksen keynesiläisestä talouspolitiikasta on esittänyt Kiander (2001), jonka mukaan keynesiläinen kysynnänsäätelypolitiikka merkitsee pyrkimystä aktiiviseen suhdannevaihteluita tasaavaan finanssipolitiikkaan. Kiander, kuten myös Jäntti ja Vartiainen (2009), laskevat devalvaatiopolitiikan, jolla pyritään aktiivisesti luomaan työpaikkoja, keynesiläiseksi politiikaksi. Tämän ajatuksen jakaa myös Juha Tarkka (1993), joka yhdistää Pekkarisen ja Vartiaisen tavoin keynesiläisen politiikan oletukseen nimellispalkkojen jäykkyydestä.

Tarkka kuitenkin laajentaa omaa keynesiläisen talouspolitiikan määrittelyään ja kritisoi Pekkarista ja Vartiaista liian kapeasta määrittelystä. Tarkan (1993) mukaan Suomessa harjoitettu teollistamis- ja kasvupolitiikka, joka perustui halpaan rahaan ja julkiseen säästämiseen "tarjoaa malliesimerkin Keynesin Yleisessä teoriassa esittämän akkumulaatio-ohjelman soveltamisesta pieneen maahan”. Tarkka (1988, 200-201) pitää ilmeisenä, että talouspolitiikka, jossa valtiolla oli vahva säästäjän ja rahoittajan rooli, ja jossa kannustettiin investointeja matalalla korolla, muistutti Keynesin esittämää politiikkaohjelmaa.

Pekkarinen ja Vartiainen (1993, 56) eivät pidä kyseistä politiikkaa keynesiläisenä, vaan yleisempänä interventionistisena talouspolitiikkana. He myöntävät, että tällaisessa säätely-interventionismissa on keynesiläisiä piirteitä, mutta koska siinä ei korosteta suhdannepolitiikkaa, investointeihin 
kannustavaa kasvu- ja teollistamispolitiikkaa ei voi määritellä tavoitteenasettelun valossa keynesiläiseksi (emt., 217).

Pekkarisen ja Vartiaisen määritelmä haastaa myös useilla muilla yhteiskuntatieteen aloilla esitetyn määritelmän, jonka mukaan keynesiläinen politiikka on yleisempää hyvinvointivaltiopolitiikkaa. Tämä määritelmä on esiintynyt ennen kaikkea poliittisen talouden tutkimusalan kirjallisuudessa, jossa toisen maailmansodan jälkeen länsimaihin muodostunutta valtiokokonaisuutta on kutsuttu keynesiläiseksi hyvinvointivaltioksi (esim. Jessop 2002). Suomessa kyseistä määritelmää on hyödynnetty ainakin poliittisen sosiologian (esim. Heiskala 2006), poliittisen maantieteen (esim. Moisio 2007; 2012; Leppänen 2011) sekä poliittisen talouden (esim. Sorsa 2014; Kananen 2014) tutkimuksessa.

Pekkarinen ja Vartiainen $(1993,53)$ perustelevat tiukempaa rajaustaan sillä, että mikäli yleistä julkisen vallan taloudelliseen kehitykseen vaikuttavaa interventiota pidettäisiin keynesiläisenä, määritelmä menettäisi selitysvoimansa, koska tällöin esimerkiksi kansallisvaltioita vertailtaessa hyvin erilaisista valtioista tulisi "keynesiläisiä". Siksi mahdollisimman selkeästi talouspolitiikan sisältöä kuvaava määritelmä on talouspolitiikan analyysissa käyttökelpoisempi.

Kun Pekkarisen ja Vartiaisen keynesiläisen talouspolitiikan määritelmää verrataan edellisessä luvussa kuvattuun Keynesin talouspoliittiseen ohjelmaan, havaitaan kiinnostavia eroja. Ensinnäkään Keynes ei perustele esittämänsä politiikkaohjelman tarvetta hintamekanismin puutteellisella toimivuudella, vaan investointi- ja säästämishalukkuuden kroonisella epätasapainolla. Koska taloudessa ei ole mekanismia, joka ajaisi investoinnit automaattisesti säästämishalukkuuden mukaisiksi, syntyy talouteen krooninen paine alikysyntään. Tämä puolestaan vaikuttaa yrittäjien odotuksiin, eikä heillä ole kannusteita työllistää niin pitkään, että täystyöllisyys taloudessa saavutettaisiin. Toisin kuin Pekkarisella ja Vartiaisella, Keynesillä talouspolitiikkaa tarvitaan rahatalouden epävakaan investointidynamiikan ja erityisesti investointipäätöksiin liittyvän epävarmuuden, ei hintajäykkyyksien, vuoksi.

Keynesin politiikkasuositusten tarkastelu osoittaa myös, ettei Keynes kannattanut julkisten kulutusmenojen ja tulojen vastasyklistä päätösperäistä sääntelyä. Keynes näki, että tällaiset toimenpiteet voisivat aiheuttaa lisää epävarmuutta yksityisten investoijien mielissä. Näin ollen meno- ja verotusperusteita tulisi lähtökohtaisesti muuttaa varoen, jos ollenkaan. Keynes kyllä 
hyväksyi James Meaden esityksen sosiaalivakuutusmaksujen vastasyklisyydestä, mutta piti muuten reagoivaa politiikkaa riittämättömänä tai jopa haitallisena.

Tässä valossa kumpikaan Pekkarisen ja Vartiaisen keynesiläisen talouspolitiikan sisällöllisistä kulmakivistä ei vastaa Keynesin omaa talouspoliittista ajattelua General Theoryn kirjoittamisen jälkeen. On kuitenkin huomattava, kuten Kregel (1994-1995) on kuvannut, että vielä 1920-luvulla ja 1930-luvulla Keynesin talouspolitiikka nojasi ajatukseen, jonka mukaan hintamekanismin toimimattomuus tai toiminnan hitaus loi edellytykset stabiloivalle talouspolitiikalle. Suuren laman aikana Keynes suositteli myös alijäämäistä julkista kulutusta yhtenä keinona elvyttää taloutta eli vastasyklisen finanssipolitiikan voidaan nähdä sisältyneen Keynesin politiikkavalikoimaan. Pekkarisen ja Vartiaisen ja muiden heidän määritelmänsä jakavien voitaisiinkin katsoa olevan lähempänä totuutta, jos he puhuisivat keynesiläisen talouspolitiikan sijaan General Theorya edeltäneestä keynesiläisestä talouspolitiikasta.

Kun Keynesin 1930-luvun lopun ja 1940-luvun alun politiikkaohjelmaa verrataan Juha Tarkan määritelmään keynesiläisestä talouspolitiikasta, havaitaan huomattavasti enemmän yhtäläisyyksiä. Kuten Tarkka on esittänyt, Keynes nosti talouspolitiikassaan matalien korkojen politiikan eksplisiittisesti keskeiseen asemaan. Keynesin ennaltaehkäisevässä investointipolitiikassa keskeisessä roolissa oli julkinen ja puolijulkinen investointitoiminta sekä julkinen rahoitus, jotka sisältyvät Tarkan määritelmään keynesiläisestä politiikasta valtiollisen kasvu- ja teollistamispolitiikan kautta.

Myös Tarkan keynesiläisen talouspolitiikan määrittelystä puuttuu Keynesin investointiohjelman suhdannevaihteluita ennaltaehkäisevän roolin ja täystyöllisyyden puolustamisen idea. Tämä johtunee siitä, että Tarkka pitää hintajäykkyyden olemassaoloa Keynesin perusteena talouspolitiikalle. Tämä ei kuitenkaan ollut Keynesin ajatus, eikä Keynes esimerkiksi esittänyt devalvaatioiden kautta toteuttavaa työllisyyspolitiikkaa kansallisen talouspolitiikan tavoitteeksi, vaikka kansainvälistä talousjärjestelmää suunnitellessaan hän antoi devalvaatiolle kroonisia talouksien välisiä epätasapainoja tasoittavan roolin (ks. Davidson 2007; Ahokas ja Holappa 2014, 286-309). 


\section{Johtopäätökset}

Tässä artikkelissa on esitelty John Maynard Keynesin talouspoliittinen ohjelma hänen pääteoksensa General Theoryn kirjoittamisen jälkeen ja vertailtu sitä suomalaisiin määritelmiin keynesiläisestä talouspolitiikasta. Keynesin talouspolitiikka osoitettiin täystyöllisyyden ylläpitämiseen pyrkiväksi ennaltaehkäiseväksi investointipolitiikaksi, jonka keskiössä ovat julkinen ja puolijulkinen investointitoiminta sekä matalien korkojen politiikka. Keynes näki, että politiikan tuli muuttua ajassa sen mukaan, miten investoinnit kehittyivät suhteessa yhteisön säästämishalukkuuteen.

Suomalaisessa julkisessa ja tieteellisessä keskustelussa keynesiläinen politiikka on ymmärretty yleensä työllisyyttä stabiloimaan pyrkivänä vastasyklisenä finanssipolitiikkana eli julkisten tulojen ja menojen säätelynä. Esimerkiksi Jukka Pekkarinen ja Juhana Vartiainen ovat käyttäneet tätä määrittelyä arvioidessaan Suomen talouspolitiikan "pitkää linjaa". Myös kansainvälisesti tämä lienee yleisin keynesiläisen talouspolitiikan määritelmä.

Artikkelin tarkastelu kuitenkin osoittaa, että Keynes suhtautui erittäin varautuneesti vastasykliseen finanssipolitiikkaan ja reagoivaan suhdannepolitiikkaan. Hän ei myöskään perustellut politiikan tarvetta hintajäykkyyksillä, kuten esimerkiksi Pekkarinen ja Vartiainen (1993) mutta myös heitä kritisoinut Tarkka (1993) ovat tehneet. On ilmeistä, että Pekkarisen ja Vartiaisen määrittelyn mukainen keynesiläinen talouspolitiikka ei vastaa Keynesin talouspoliittisia suosituksia General Theoryn julkaisun jälkeen.

Juha Tarkka on lähempänä Keynesin talouspoliittista ajattelua sisällyttäessään keynesiläisen talouspolitiikan määritelmään myös matalien korkojen politiikan ja valtiollisen kasvu- ja teollistamispolitiikan. Molempien kokonaisuuksien voidaan katsoa sisältyvän Keynesin politiikkaohjelmaan. Kuitenkaan myöskään Tarkan määritelmässä ei korosteta riittävästi ennakoivaa ja ennalta vakauttavaa investointipolitiikkaa tai täystyöllisyyttä "puolustavaa" näkökulmaa.

Mitä yhteiskunnallista merkitystä keskustelulla keynesiläisen talouspolitiikan määrittelystä sitten on? Ennen kaikkea sillä on merkitystä siihen, kuinka historiassa harjoitettua ja tällä hetkellä sekä tulevaisuudessa harjoitettavaa talouspolitiikkaa tulkitaan. Esimerkiksi Pekkarisen ja Vartiaisen suomalaisesta talouspolitiikasta tekemä johtopäätös, jonka mukaan maassamme 
harjoitettu talouspolitiikka ei ole ollut keynesiläistä, riippuu suoraan heidän tekemästään keynesiläisyyden määrittelystä. Jos suomalaisen talouspolitiikan historiallisessa tarkastelussa käytetään Juha Tarkan määritelmää, johtopäätös on täysin eri.

Riippuen keynesiläisen talouspolitiikan määrittelystä lopputuloksena on siis kaksi eri tulkintaa: 1) Suomessa talouspolitiikka erosi merkittävästi muista länsimaista toisen maailmansodan jälkeen eikä keynesiläistä vallankumousta koskaan varsinaisesti tapahtunut Suomessa, tai 2) Suomessa seurattiin melko tarkasti toisen maailmansodan jälkeistä keynesiläistä talouspolitiikan doktriinia, joka korvasi aiemman liberalistisen doktriinin. Tulkintaerot voivat vaikuttaa myös siihen, miten Keynesin politiikkasuosituksiin ja keynesiläisyyteen suhtaudutaan nykyistä talouspolitiikkaa suunniteltaessa.

Määrittelemällä keynesiläinen talouspolitiikka tässä artikkelissa esitetyn Keynesin oman talouspoliittisen ohjelman mukaiseksi talouspolitiikaksi sekä tarkastelemalla suomalaista talouspolitiikkaa (ohjelmallista ja toimeenpantua) tästä näkökulmasta, voidaan kysymykseen tulevaisuudessa saada kolmas vaihtoehtoinen vastaus. Tämän vastauksen kiinnostavuus liittyy ensinäkin siihen, että se huomioi Keynesin talousteoreettisen ajattelun kehityksen ja nojaa Keynesin pääteoksessaan General Theoryssa esittämään teoreettiseen viitekehykseen. Puhuttaessa "Keynesin vallankumouksesta", johon myös talouspolitiikan kehitys toisen maailmansodan jälkeen usein liitetään, viitataan yleensä juuri tähän teoriaan.

Toiseksi tässä artikkelissa esitetyn keynesiläisen talouspolitiikan määritelmä on kiinnostava suomalaisen talouspolitiikan viime vuosikymmenten historian analyysille siksi, että Keynes esitti talouspoliittisen ohjelmansa kattavaksi vastaukseksi nimenomaan toista maailmansotaa seuraavan rauhanajan taloudellisiin ongelmiin. Kun Keynesin vielä 1930-luvun alussa esittämät politiikkasuositukset oli kohdennettu lamaolosuhteisiin, 1940-luvun politiikkasuositukset tarjosivat ratkaisuja talouden eri kehitysvaiheisiin, joita Keynes ennakoi ohjelmaansa kirjoittaessaan.

Kansainväliset esimerkit osoittavat, että eri keynesiläisyyden määritelmien kautta talouspolitiikan analyysiin on löydettävissä sitä oleellisesti rikastavia elementtejä. Esimerkiksi Isossa-Britanniassa keskustelu keynesiläisen talouspolitiikan määritelmästä on laajentanut mielenkiintoisella tavalla taloushistoriallista näkemystä maassa toisen maailmansodan jälkeen harjoitetusta 
talouspolitiikasta (ks. Tomlinson 1981; 1984; Booth 1983; 1984; Rollings 1988).

Vaikka taloustieteen piirissä yleisin lähtökohta on ollut tarkastella keynesiläistä talouspolitiikkaa yksinkertaisesti vastasyklisenä finanssipolitiikkana, myös laaja-alaisempaa keskustelua keynesiläisen talouspolitiikan määritelmästä on käyty (ks. Meltzer 1981; Patinkin 1983; Colander 1984; Cunningham ja Vilasuso 1994-1995; Wray 1994-1995; Galbraith 1994-1995).

Nämä keskustelut osoittavat, että määrittelemällä keynesiläinen politiikka Keynesin General Theoryn jälkeiseen omaan talouspoliittiseen ajatteluun nojautuen päästään harjoitetun talouspolitiikan analyysissa varsin erilaisiin tuloksiin kuin siinä tapauksessa, että keynesiläinen politiikka ymmärrettäisiin yksinkertaisesti vastasyklisenä finanssipolitiikkana. Siksi myös Suomen talouspolitiikan toisen maailmansodan jälkeistä historiaa on tulevaisuudessa mielekästä analysoida ottamalla lähtökohdaksi tässä artikkelissa esitelty Keynesin talouspoliittinen ohjelma.

\section{Viitteet}

I) Kirjoittaja kiittää Palkansaajasäätiötä tutkimuksen mahdollistaneesta apurahasta. Kiitokset myös käsikirjoitusta eri vaiheessa kommentoineille henkilöille: anonyymille vertaisarvioijalle, Poliittinen talous -lehden työpajaan osallistuneille sekä Lauri Holapalle ja Elina Aaltiolle.

2) Keynesin tuotannosta esitetyt suorat lainaukset ovat kirjoittajan suomentamia.

\section{Lähteet}

Ahokas, Jussi ja Holappa, Lauri. 2014a. Miksi Keynes ei palannutkaan? Tiede ja edistys, 39:1, 5-33.

Ahokas, Jussi ja Holappa, Lauri. 2014b. Rahatalous haltuun - Irti kurjistavasta talouspolitiikasta. Helsinki: Like. 
Booth, Alan. 1983. The "Keynesian Revolution" in Economic Policy-Making. The Economic History Review, 36:1, 103-123.

Booth, Alan. 1984. Defining a "Keynesian Revolution". The Economic History Review, 37:2, 263-267.

Brown-Collier, Elba ja Collier, Bruce. 1995. What Keynes Really Said about Deficit Spending. Journal of Post Keynesian Economics, 17:3, 341-355.

Burda, Michael ja Wyplosz, Charles. 2013. Macroeconomics. Oxford: Oxford University Press.

Chick, Victoria. 1983. Macroeconomics after Keynes - A Reconsideration of the General Theory. Oxford: Philip Allan Publishers Limited.

Colander, David. 1984. Was Keynes a Keynesian or a Lernerian? Journal of Economic Literature, 22:4, 1572-1575.

Cunningham, Steven ja Vilasuso, Jon. 1994-1995. Is Keynesian demand management policy still viable? Journal of Post Keynesian Economics, 17:2, 187-210.

Davidson, Paul. 1972. Money and the Real-World. New York: Palgrave Macmillan.

Davidson, Paul. 2009. The Keynes Solution: The Path to Global Economic Prosperity. New York: Palgrave Macmillan.

Dillard, Dudley. 1980. A Monetary Theory of Production: Keynes and the Institutionalists. Journal of Economic Issues 14:2, 255-273.

Fontana, Giuseppe ja Realfonzo, Riccardo (toim.). 2005. The Monetary Theory of Production: Tradition and Perspectives. New York: Palgrave Macmillan. Galbraith, James K. 1994-1995. John Maynard Nosferatu. Journal of Post Keynesian Economics, 17:2, 249-260.

Gali, Jordi. 2005. Modern Perspectives on Fiscal Stabilization Policies. CESifo Economic Studies, 51:4, 587-599.

Giles, Chris. 2013. IMF adopts a more Keynesian line on deficits and stimulus. Financial Times. 10.10.2013. http://www.ft.com/content/7dc8b574-29f411e3-9bc6-00144feab7de [Luettu: 10.12.2016]

Heiskala, Risto. 2006. Kansainvälisen toimintaympäristön muutos ja Suomen yhteiskunnallinen murros. Teoksessa Risto Heiskala ja Eeva Luhtakallio (toim.) Uusi jako: miten Suomesta tuli kilpailukyky-yhteiskunta. Helsinki: Gaudeamus, 14-42. 
Hurri, Jan. 2010. Tätä läksyä Eurooppa ei oppinut. Taloussanomat. 3.10.2010. http://www.iltasanomat.fi/taloussanomat/art-2000001687559.html [Luettu: 10.12.2016]

Hurri, Jan. 2014. Elvytystä ja kiristystä mutta ei kunnolla kumpaakaan.

Taloussanomat. 9.2.2014. http://www.iltasanomat.fi/taloussanomat/ porssiuutiset/art-2000001825689.html [Luettu: 10.12.2016]

Jahan, Sarwat, Saber Mahmud, Ahmed ja Papageorgiou, Chris. 2014. What Is Keynesian Economics? Finance \& Development, 51:3, 53-54.

Jessop, Bob. 2002. Liberalism, Neoliberalism, and Urban Governance: A State Theoretical Perspective. Antipode 34:3, 452-472.

Johnson, Elizabeth. 1974. John Maynard Keynes: Scientist or Politician? Journal of Political Economy, 82:1, 99-111.

Jäntti, Markus ja Vartiainen, Juhana. 2009. The Finnish Developmental State and its Growth Regime. Research Paper No. 2009/35.

Kananen, Johannes. 2014. The Nordic Welfare State in Three Eras: From Emancipation to Discipline. Farnham: Ashgate.

Kangas, Olli ja Saloniemi, Antti. 2013. Historical making, present and future challenges for the Nordic welfare state model in Finland. Fafo-report 2013:40.

Kanniainen, Vesa. 2012. Talouskriisit ovat yleisempiä kuin mustat joutsenet. Tieteessä tapahtuu, 4/2012, 65-66.

Keynes, John Maynard. 1930a. A Treatise on Money. Lontoo: Macmillan. Keynes, John Maynard. 1930b. Economic Possibilities for Our Grandchildren. Teoksessa John Maynard Keynes. 2010. Essays in Persuation. Lontoo: Palgrave Macmillan, 321-332.

Keynes, John Maynard. 1936. The General Theory of Employment, Interest and Money. Lontoo: Macmillan.

Keynes, John Maynard. 1937. The General Theory of Employment. The Quarterly Journal of Economics, 51:2, 209-223.

Keynes, John Maynard. 1963 [1933]. On the Theory of a Monetary Economy. Nebraska Journal of Economics and Business 2:2, 7-9.

Keynes, John Maynard. 1972. The Collected Writings of John Maynard Keynes IX. Cambridge: Cambridge University Press.

Keynes, John Maynard. 1980. The Collected Writings of John Maynard Keynes XXVII. Cambridge: Cambridge University Press. 
Kiander, Jaakko. 2001. Laman opetukset - Suomen 1990-luvun kriisin syyt ja seuraukset. VATT Julkaisuja 27:5.

Korkman, Sixten. 2015. Väärä talouspolitiikkaa - talouden kriisit ja opilliset kiistat. Helsinki: Otava.

Koskela, Erkki. 1996. Talouspoliittisen ajattelun muuttuminen 1930-luvulta nykypäivään. Kansantaloudellinen aikakauskirja, 94:4, 398-409.

Kregel, Jan. 1985. Budget Deficits, Stabilization Policy and Liquidity Preference: Keynes's Postwar Policy Proposals. Teoksessa Fausto Viccarelli (toim.). Keynes's Relevance Today. Lontoo: Macmillan, 28-50.

Kregel, Jan. 1994-1995. The Viability of Economic Policy and the Priorities of Economic Policy. Journal of Post Keynesian Economics, 17:2, 261-277.

Kregel, Jan. 1998. Aspects of a Post Keynesian Theory of Finance. Journal of Post Keynesian Economics, 21:1, 111-133.

Krugman, Paul. 2005. Is Fiscal Policy Poised for a Comeback? Oxford Review of Economic Policy, 21:4, 515-523.

Krugman, Paul. 2015. Keynesianism Explained. http://krugman.blogs.nytimes. com/2015/09/15/keynesianism-explained/ [Luettu 10.12.2016].

Leppänen, Laura. 2011. Changing statehood: The spatial transformation of the Finnish state. Annales Universitatis Turkuensis AII, osa 260. Turku: Turun yliopisto.

Lerner, Abba. P. 1943. Functional Finance and the Federal Debt. Social Research, 10:1, 38-51.

Meltzer, Allan. 1981. Keynes's General Theory: A Different Perspective. Journal of Economic Literature, 19:1, 34-64.

Minsky, Hyman P. 1975. John Maynard Keynes. New York: Columbia University Press.

Moggridge, Daniel. 2002. Maynard Keynes: An Economist's Biography. Lontoo: Routledge.

Moisio, Sami. 2007. Valtiomuutoksen tuottaminen Suomessa - poliittisen maantieteen näkökulma. Politiikka 49:4, 229-247.

Moisio, Sami. 2012. Valtio, alue, politiikka: Suomen tilasuhteiden sääntely toisesta maailmansodasta nykypäivän. Tampere: Vastapaino.

Okko, Paavo. 2008. Havaintoja Suomen talouden kehityksestä ja talouspolitiikan linjasta sekä taloustieteen roolista sen tukena. Kansantaloudellinen aikakauskirja, 104:1, 103-110. 
Patinkin, Don. 1983. New Perspectives or Old Pitfalls? Some Comments on Allan Meltzer's Interpretation of the General Theory. Journal of Economic Literature, 21:1, 47-51.

Pekkarinen, Jukka. 1988. Keynesianism and the Scandinavian Models of

Economic Policy. Wider Working Papers, 1988/35.

Pekkarinen, Jukka ja Sutela, Pekka. 2002. Kansantaloustiede. Helsinki: WSOY.

Pekkarinen, Jukka ja Vartianen, Juhana. 1993. Suomen talouspolitiikan pitkä linja.

Juva: Werner Söderström Osakeyhtiö.

Rollings, Neil. British budgetary policy 1945-1954: a "Keynesian revolution"?

The Economic History Review, 41:2, 283-298.

Saari, Juho 2005. Hyvinvointivaltio ja sosiaalipolitiikka. Teoksessa Juho Saari (toim.)

Hyvinvointivaltio - Suomen mallia analysoimassa. Helsinki: Gaudeamus, 13-62.

Skidelsky, Robert. 2003. John Maynard Keynes: 1883-1946: Economist,

Philosopher, Statesman. New York: Penguin Books.

Sorsa, Ville-Pekka. 2014. Suomalaisen kilpailuvaltion hallintastrategia:

koordinaatiota ilman synergioita? Tiede \& edistys. 39:3, 195-213.

Tarkka, Juha. 1993. Onko suhdannepolitiikka vain tahdon asia?

Kansantaloudellinen aikakauskirja, 89:2, 275-280.

Tarkka, Juha. 1988. Kahlitun rahan aika: Suomen rahoitusmarkkinoiden säännöstelyn vuosikymmenet. Teoksessa Seppo Honkapohja ja Antti Suvanto (toim.), Raha, inflaatio ja talouspolitiikka. Helsinki: Valtion Painatuskeskus, 189-250.

Tcherneva, Pavlina. 2008. Keynes's Approach to Full Employment: Aggregate or Targeted Demand? Levy Economics Institute Working Paper No. 542.

Tcherneva, Pavlina. 2012. Permanent On-The-Spot Job Creation-The Missing Keynes Plan for Full Employment and Economic Transformation. Review of Social Economy, 70:1, 57-80.

Tomlinson, Jim. 1981. Why was there never a "Keynesian Revolution" in Economic Policy? Economy and Society, 10:1, 73-87.

Tomlinson, Jim. D. 1984. A "Keynesian Revolution" in Economic PolicyMaking? The Economic History Review, 37:2, 258-262.

Wray, Randall. 1994-1995. Is Keynesian policy dead after all these years? Journal of Post Keynesian Economics, 17:2, 285-306.

Wray, Randall. 2007. Veblen's theory of business enterprise and Keynes's monetary theory of production. Journal of Economic Issues 41:2, 617-624. 